\title{
Impressions of Russian Technical Education
}

\author{
An interview with Professor Morris Cohen of the Massachusetts Institute of \\ Technology produced some interesting comments on technical education in \\ the USSR.
}

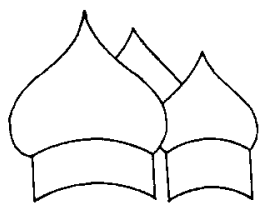

\begin{abstract}
"The Russians are training good engineers" was Professor Cohen's reply to questions about the adequacy of Soviet education. We put it this way, "There is an impression that the Soviets have been training technicians rather than educating engineers. We gather that the Russian technical schools, with their close links to industry, attempt to train for a specific type of job, almost in a specific plant. Doesn't this type of approach result in a very narrow engineer who can not adapt himself to new situations and different ideas and problems?"'

"No", said Professor Cohen, and he went on to point out that Soviet education is an overall integrated system; therefore, one must look at the primary and secondary education as a part of the whole. It is in the secondary schools that the potential engineer starts the fundamentals of mathematics, physics, and chemistry, while he is given two to three years of basic and applied science in technical institutes before beginning to specialize in a relatively narrow area during his last two years of formal education. It is this background, building up step by step through the fundamentals for 10 years in primary and secondary schools plus two of the college years that produces a well rounded engineer. "The Soviets have good general engineers in spite of their specialization", concluded the professor.
\end{abstract}

Are the humanities neglected? This was our next question posed to professor Cohen. "They are not emphasized to the extent that they are in America, but they are not completely neglected either. Here again you must look at the overall educational pregram, including primary and secondary schools. It is in the grade schools that humanities, such as literature, history, geography, art, and music are taught. Soviet educators apparently feel, that upon reaching the university level the student has largely completed this phase of his education. Economics, foreign languages, physical education, philosophy and Marxism-Leninism are just about the only nontechnical subjects offered in technical colleges. There appears to be no such thing as a liberal arts education in Soviet universities, although a student may specialize in history, law economics, and similar fields."

Can most Soviet metallurgists read English? "Most of those we met could certainly read English, although few were able to speak to us without interpreters," replied Professor Cohen, who explained that six years of foreign language are required in primary and secondary schools, starting in the fourth or fifth grades. Five additional years are required in the university. The greatest emphasis by far is on English, although German and French are also important.

How does secondary education compare with the US? The answer did not appear to be difficult for Dr. Cohen, who pointed out that Soviet secondary school students are not provided with a wide array of electives which they may take at almost any time and in almost any sequence. "Each subject is introduced in what is felt to be the proper order. Mathematics through trigonometry, chemistry, physics, biology, and astronomy are required in all secondary schools as a part of the general education. Entrance examinations are a necessary prerequisite for admission to any higher educational institution, and all examinations are of the same level, requiring a fundamental knowledge of mathematics and science, as well as Russian, and a foreign language."

Is there an overly formal atmosphere in colleges? "Well, the students certainly do have the same respect for professors that is characteristic of German universities. There is little or no social intercourse between students and faculty. It would appear that students generally accept the teachings of their professors without much question, but this is not so much a matter of regimented obedience as of respect."

What about the economic position of professors? "University professors are certainly at the top of the economic, as well as the social, ladder, and their earnings are from ten to fifty times those of laborers. There appears to be no shortage of teachers. By means of the stipends paid to college students it is quite easy to control the flow of students into the various professions by regulating the value of stipends. Furthermore, the young person in the Soviet Union is attracted to higher education, since the stipends are commensurate with wages paid to common laborers."

How do you feel about your reception in the USSR? Dr. Cohen felt that he was given excellent opportunities to visit research institutes and talk with specialists in various fields. Certain things were not shown, but on the other hand, the Russians were not shown everything on their visits to the US. Dr. Cohen feels that there is a good chance for a gradual opening up on both sides.

Summarizing, the main points which Professor Cohen brought out on Russian technical education:

1) Russian engineers are not overspecialized for their purposes when one considers the amount of basic and applied science given them in secondary schools and in their first two years of higher education;

2) The teaching of science and engineering is firmly based on the educational process of the secondary school system. Russian education must be considered as a whole, since it is part of an integrated plan;

3) Every student in the secondary schools must take stiff courses in science and mathematics; and

4) The humanities are virtually neglected in higher education for scientists and engineers. Apparently, reliance is placed on the secondary schools for the non-technical subjects. 